\title{
PROGRAM PENDAMPINGAN BERBASIS KEARIFAN LOKAL DESA ADAT SENARU DALAM MENINGKATKAN MOTIVASI BELAJAR ANAK-ANAK DESA ADAT SENARU
}

(Program Pengabdian Kepada Masyarakat di Desa Adat Senaru Kecamatan Bayan Kabupaten Lombok Utara)

\author{
Euis Eti Rohaeti ${ }^{1}$, Putri Nabila N.S ${ }^{2}$, Anas Muharrom ${ }^{3}$ \\ 1, 2, 3 IKIP SILIWANGI \\ e2rht@ikipsiliwangi.ac.id
}

\begin{abstract}
ABSTRAK
Program pengabdian kepada masyarakat adalah salah satu bagian dari tridharma perguruan tinggi. Oleh karena itu, menjadi suatu kewajiban bagi setiap dosen dan sivitas akademika lainnya untuk terlibat dalam program pengabdian kepada masyarakat. Kegiatan pengabdian masyarakat ini dilaksankan di desa adat Senaru Kecamatan bayan Kabupaten Lombok utara dengan tujuan jangka panjang program pengabdian ini adalah mengembangkan suatu pembelajaran ekstrakulikuler dengan pendampingan berbasis kearifan lokal bagi anak-anak usia SD. Secara khusus, tujuan yang ingin dicapai sebagai berikut: (1). Meningkatkan motivasi belajar anak-anak SD di Desa adat Senaru; (2). Melestarikan kearifan lokal Desa adat Senaru. Metode yang akan dipakai dalam upaya pencapaian tujuan tersebut memalui pendampingan berbasis kearfian lokal yang langkahlangkahnya terdiri dari: (1). mengkaji kearfian lokal; (2). mempersiapkan materi yang sesuai dengan usia SD khusunya mata pelajaran matematika dan bahasa Indonesia; (3). Melakukan pendampingan berbasis kearifan lokal; (4). Melakukan refleksi dan terkait proses pendampingan; (d). Evaluasi kegiatan pendampingan berbasis kearifan lokal. Hasil dari pengabdian ini terdapat peningkatan motivasi belajar siswa

Kata Kunci : Pendampingan, kearifan lokal, motivasi belajar
\end{abstract}

\begin{abstract}
The community service program is one part of the tridharma of higher education. Therefore, it is an obligation for every lecturer and other academic community to be involved in community service programs. The community service activities are carried out in the traditional village of Senaru, Bayan Sub-district, North Lombok Regency. The long-term goal of this service program is to develop an extracurricular learning program with local wisdom-based assistance for elementary school children. Specifically, the specific objectives to be achieved are as follows: (1). Increase learning motivation of elementary school children in the traditional village of Senaru; (2). Preserve the local wisdom of the Senaru traditional village. The method that will be used in an effort to achieve these objectives is through local religious-based assistance whose steps consist of: (1). study local jurisprudence; (2). preparing material that is suitable for elementary school age especially in mathematics and Indonesian; (3). Providing assistance based on local wisdom; (4). Reflecting and related mentoring processes; (4). Evaluation of local wisdom based mentoring activities.
\end{abstract}

Keywords: Mentoring, local wisdom, learning motivation

\section{A. PENDAHULUAN}

Undang-Undang Sistem Pendidikan Nasional No. 20 Tahun 2003 menyebutkan bahwa pendidikan merupakan usaha sadar dan terencana untuk mewujudkan suasana belajar dan proses pembelajaran agar peserta didik secara aktif mengembangkan potensi dirinya untuk 
memiliki kekuatan spiritual keagamaan, pengendalian diri, kepribadian, kecerdasan, akhlak mulia, serta keterampilan yang diperlukan dirinya, masyarakat, bangsa dan Negara.

Dari pendapat diatas bahwa pendidikan merupakan usaha sadar dan terencana untuk mengupayakan suatu pembelajaran yang bisa mengembangkan mutu dan potensi siswa agar bisa mengendalikan kemampuannya. Salah satu konsep agar siswa mampu mengembangkan potensinya adalah dengan cara belajar. Belajar merupakan kebutuhan yang harus dipenuhi oleh siswa karena dengan belajarlah siswa dapat memperoleh ilmu pengetahuan yang luas dan mampu mengubah tingkah lakunya.

Belajar yang diharapkan sesuai dengan pernyataan di atas adalah belajar dengan suasana yang aktif dan mampu memberikan motivasi kepada siswa agar semangat dalam mengikuti prose belajar tersebut. Salah satu upaya yang dapat dilaksankan dalam menciptakan suasana belajar yang diharapkan mampu menciptakan motivasi belajar siswa yaitu dengan adanya modifikasi proses pembelajaran salah satunya pada kegiatan ini menggunakan kearfian lokal sebagai media pada saat belajar atau sebagai ice breaking disela-sela proses belajar. Kearifan lokal yang digunakan pada kegiatan pengabdian ini adalah kearfian lokal yang ada di Desa Adat Senaru seperti kayak, cepung, tembang, oncer/gendan beleq/kecodak, cupak, dan rudat.

Pemilihan kegiatan pendampingan berbasis kearfian lokal berdasarkan hasil penelitian yang telah dilakukan oleh Efendi (2014) dengan judul implementasi kearifan budaya lokal pada masyarakat adat kampung kuta sebagai sumber pembelajaran IPS dan Anggramayeni, dkk efektivitas bahan ajar berbasis kearifan lokal terhadap aktivitas dan hasil belajar peserta didik (2018) dari kedua hasil penelitian tersebut dapat disimpulkan bahwa kearifan lokal dapat dimanfaatkan untuk kegiatan pembelajaran. Oleh karena itu pada program pengabdian ini mengangkat judul program pendampingan berbasis kearifan lokal desa adat Senaru dalam meningkatkan motivasi belajar anak-anak desa adat Senaru.

\section{B. LANDASAN TEORI}

\section{Keadaan Geografis dan Demografis Pulau Lombok}

Lombok adalah sebuah pulau yang terletak di bagian timur Indonesia, yaitu pulau yang merupakan bagian dari wilayah provinsi Nusa Tenggara Barat. Pulau ini cukup populer dikenal dengan sebutan pulau seribu masjid. Identitas pulau seribu masjid yang disandang tidak terlepas dari keberadaan pulau ini yang hampir setiap lingkunga dusun 
dihiasi dengan berdirinya masjid dan beberapa langgar atau musola. Bagi para musafir atau wisatawan yang baru berkunjung kepulau ini, tidak kesulitan mendapatkan tempat ibadah setiap waktu sholat tiba. Menjamurnya masjid ini disebabkan karakter dan watak dari masyarakat suku sasak yang menghuni pulau ini dikenal sebagai penganut agama islam yang sangat kuat dalam keyakinan (Widianti, 2017).

Keyakinan uang kuat akan ajaran islam menjadikan masyarakatnya memiliki sifat jujur atau lulus. Sifat inilah yang kemudian menurut sebagian ahli menjadi latar belakang penamaan dari pulau lombok ini sendiri, dari kata "lombo" yang berarti lurus. Namun karena bervariasinya bukti-bukti yang ditemukan sebagai pendukung penamaan pulau lombok ini maka peresepsi tentang nama pulau ini sangat berbeda diantara para ahli.

Secara geografis pulai Lombok terbagi menjadi beberapa daerah, yaitu :

a. Daerah pegunungan bagian utara yang berpuncak pada gunung rinjani dengan ketinggian 3.726 MDPL dan gunung sangkarena dengan tinggi 2.588 MDPL. Keberadaan dua gunung ini memberikan dampak kesuburan terhadap daerah pesawahan yang berada di lombok bagian tengah. Dari gunung inilah mengalir air yang diperlukan untuk pertanian, berkebunan, dan sebagainya. Kedua gunung ini merupakan kawasan hutan belantara yang saat ini menjadi salahsatu kawasan hutan lindung dan daerah wisata yang paling menantang untuk dikunjungi. Karena diatas gunung Rinjani terdapat sejumlah sumber air dengan berbagai rasa, mulai dari yang paling dingin sampai yang paling panas.

b. Daerah yang terletak di sebelah utara gunng rinjani. Daerah ini termasuk daratan rendah yang melingkari kaki gunung Rinjani. Karena kurnagnya curah hujan disekitar daerha ini disamping daerahnya yang cenderung berpasir, maka tanaman palawijaya yang berumur pendeklah yang paling cocok dikawasan ini.

c. Daerah dataran tengah, daerah ini termasuk daerah yang paling subur dan paling padat penduduk yang mendiaminya. Kesuburan ini tidak terlepas dari geografisnya yang rata dan berada pada posisi lebih rendah dan daerah pegunungan bagian utara pulau Lombok. Keberadaan daerha yang demikian menjadikannya subur dan mendukung keberhasilan para penduduk yang mendiaminya untuk bercocok tanam.

d. Daerah perbukitan bagian selatan, yang terdiri dari dua buah semenanjung, yaitu yang benjolok ke Selat Alas disebelah timur dan ke Selat Lombok disebelah barat. Sebagian besar daerah ini termasuk daerah tadah hujan dengan jenis tanah 
gromusol (tanah liat) dan cenderung tandus. Lahat pertanian berupa daerah pesawahan yang demikian luas tidak bisa secara rutin produktif untuk ditanami. Kecuali pada musim penghujan. Sebagian besar penghuninya mengandalkan pertanian sebagai sumber pendapatan.

e. Daerah Bagian Tenggara, daerah ini hampir sama dengan daerah bagian selatan. Tanah didaerah ini berjenis gromusol (tanah liat). Namun karena sistem irgasi, pengairannya kurang baik, sehingga daerah ini tergolong lahan tadah hujan. Bersamaan dengan daerah bagian selatan yang mendapat perhatian dari pemerintah Canada sejak tahun 1986 hingga pengairan teknis dan sebagiannya mulai subur.

\section{Desa Adat Senaru}

Selama beberapa hari tinggal di desa adat senaru, kecamatan Bayan. Berdasarkan hasil observasi dan wawancara dengan warga setempat Desa ini cukup terkenal terutama bagi para pendaki Gunung Rinjani, karena desa ini merupakan salah satu gerbang pendakian ke puncak Rinjani. Di desa ini juga terdapat beberapa air terjun yang terkenal dengan keindahannya. Selain itu desa senaru juga memiliki sebuah kampung adat suku sasak yang masih terjaga keasliannya. Di Lombok utara memang terdapat beberapa kampung adat yang rumah warga-warganya masih tradisional. Kampung adat senaru berada persis digerbang pendakian senaru. Untuk menuju kedesa senaru dari kota mataram memerlukan waktu 2,5 sampai 3 jam dengan jarat tempuh $86 \mathrm{~km}$. Disana kami melakukan wawancara dengan warga asli kampung adat senaru kita juga banyak berbincang dan berbicara dengan ketua/pemangku adat kampung senaru. Ketua adat kampung senaru berbicara bahwa kampung ini sudah dari dulu bentuknya seperti ini, tidak pernah berubah dan memang sengaja dijaga keasliannya untuk mengenal kampung tradisional Lombok Utara kepada para wisatawan. Kampung ini dulu merupakan wilayah kerajaan bayan. Sebuah kerajaan di Lombok Utara.

Rumah-rumah dikampung ini semuanya masih terbuat dari bahan yang sama. Beratap alang-alang dan bambu serta berlantai tanah atau semen batu. Dindingnya terbuat dari bambu yang dianyam. Bentuk rumah-rumahnya juga seragam dan memiliki empat tiang yang disebut dengan sekepat. Selain bangunan rumah utama, diantara rumah-rumah ini juga terdapat brugaq, tempat masyarakat berkumpul atau menerima tamu. Selain bangunan brugaq, terdapat pula bangunan bumi gora yaitu lumbung padi tradisional yang berbentuk panggung, tempat menyimpan hasil panen padi dan yang 
lainnya. Masyarakat dikampung sebagian besar bermata pencaharian sebagai petani dan peternak. Mereka menanam padi serta berkebun coklat, kopi, cengkeh dan yang lainnya. Mereka biasanya berternak sapi, kerbau, ayam. Sapi dan kerbaunya ditempatkan di pinggir rumah mereka masing-masing, didikat disebuah kayu besar. Mereka juga masih memasak menggunakan tungku kayu bakar, namun sudah ada beberapa rumah menggukan gas LPJ. Kayu-kayu disimpan berada dibawah brugaq. Ada hal yang sangat unik yang terdapat di Desa Adat Senaru yaitu rasa gotong royong yang masih kuat, ketika ada Salah seorang warga ada yang akan membuat rumah seluruh masyaakat di desa adat senaru akan membantu dan berpartisipasi dalam pembuatan rumah tersebut. Seluruh masyarakat desa adat senaru khususnya bagi para pria memakai pakaian dodot (pakaian adat) ketika pembangunan rumah adat, sedangkan para wanita berkerja di dapur untuk memasak makanan bagi para pria.

Disamping itu, dalam bidang seni dilombok terdapat jenis kesenian/seni yaitu sebagai berikut :

a. Kayak, suatu jenis suara vokal yang terdapat diseluruh lombok. Bentuknya berbaitbait jenis pantun.

b. Cepung, suatu jenis suara vokal yang diiringi dengan rebab dan seruling serta ditambah dengan gerak-gerak sederhana dari penyanyi.

c. Tembang, suatu jenis suara vokalyang hidup dimayarakat lombok, terutama desadesa. Jenis ini keberadaannya hanya untuk mengisi keramaian-keramaian yang berhubungan dengan adat.

d. Oncer / Gendan Beleq/ Kecodak, yaitu suatu jenis tari yang dibawakan sambil memainkan instrumentalia. Seni ini untuk melambangkan/melukiskan gerak-gerak peperangan. Tarian ini biasanya dipertunjukan saat ada acara perkawinan, khitanan dan kegiatan adat lainnya.

e. Cupak, suatu jenis kesenian yang melakonkan copak (petikan dari cerita panji). Kesenian ini dimainkan oleh beberapa orang diatas panggung. Umumnya kesenian ini menampilkan cerita yang berkaitan dengan dua hal yang selalu berlawanan yaitu kebaikan dan keburukakan. Dan pada akhir ceritanya di dapat suatu kesimpulan bahwa kebenaran itu selalu benar.

f. Rudat, kesenian rudat ini dilakukan sama dengan kesenian cupak, bedanya kalau cupak lebih mengisahkan tentang antara baik dan benar. Sedangkan rudat lebih banyak mengisahkan tentang perjalanan hidup sebuah kerajaan. Rudat ini dalam 
cerita kisahnya lebih menyentuh tentang hal-hal yang ada kaitannya seorang peminpin dnegan bawahannya. Rudat ini kadang berbentuk sebuah drama yang umumnya menjadi tontonan masyarakat.

Motto Desa Adat Senaru adalah "ontas onang onyak" yang bermakna "ketika ingin melaksanakan sesuatu sebaiknya direncankan atau dirintis dengan baik terlebih dahulu agar dinikmati, dirasakan, digunakan, dan dimanfaatkan hasilnya, yang kemudian perlu memeliharanya agar bisa digunakan kembali baik untuk kebutuhan pribadi atau kebutuhan bersama.

\section{Program Pendampingan Berbasis Kearifan Lokal}

Pendampingan merupakan suatu proses kegiatan yang didalamnya memuat sifatsifat atau karakteristik pendampingan seperti konsultatif, interaktif, komunikatif, motivatif, dan negosiatif. Konsultatif yang dimaksud adalah menciptakan suatu kondisi dimana pendamping maupun yang didampingi bisa berkonsultasi dalam memecahkan masalah bersama-sama, interaktif artinya antara pendamping dan yang didampingi harus sama-sama aktif, komunikatif maksudnya adalah apa yang disampaikan pendamping atau yang didampingi dapat dipahami bersama, motivatif maksudnya pendamping harus dapat menumbuhkan kepercayaan diri dan dapat memberikan semangat/motivasi kepada yang didamping, serta negosiatif artinya ketika prose pendampingan berlangsung antara pendamping dan yang didampingi mudah melakukan penyesusaian baik dari segi bahasa, bahasan, ataupun waktu pelaksanaan pendampingan Kamil (Rahayu dan Firmansyah, 2018).

Proses pendampingan berbasis kearfian lokal yang dilaksankan pada pengabdian ini didalamnya memuat kearifan lokal yang ada di Desa Adat Senaru dalam proses pendampingan seperti ketika proses pendampingan dalam upaya meningkatkan motivasi belajar diselingi dengan kearfian lokal Oncer / Gendan Beleq/ Kecodak sehingga anak-anak tidak jenuh dengan proses pendampingan yang berlangsung. Selain kearifan lokal Oncer / Gendan Beleq/ Kecodak terdapat juga kearifan lokal kayak berupa pantun-pantun, dan Cepung berupa suara vola dengan musik-musik instrumental.

\section{Motivasi Belajar}

Motivasi belajar merupakan salah satu indicator dari keberhasilan proses pembelajaran. Terdapat dua hal yang dapat mempengaruhi motivasi belajara yaitu faktor eksternal dan faktor internal. Faktor internal yaitu motivasi yang berasal dari dalam diri anak tersebut seperti 
keadaan sehat atau tidak sehat sedangkan faktor eksternal adalah faktor yang berasal dari luar diri anak tersebut seperti faktor media pembelajaran, keadaan lingkungan sekitar, faktor guru/pendamping, serta faktor eksternal lainnya yang dapat mempengaruhi motivasi belajar anak. (Mangewa, 2010; Alannasir, 2016).

Sardiman (Suprihatin, 2015) mengemukakan motivasi belajar memiliki indikator sebagai berikut:
a. Tekun menghadapi tugas
b. Ulet menghadapi kesulitan (tidak lekas putus asa)
c. Menunjukan minat terhadap bermacam-macam masalah orang dewasa.
d. Lebih senang bekerja mandiri
e. Cepat bosan pada tugas rutin
f. Dapat mempertahankan pendapatnya

\section{METODE PELAKSANAAN}

Pelaksanaan pada program pengabdian kepada masyarakat ini dilaksanakan selama 1 minggu mulai dari tanggal 29 Juli-4 Agustus 2018 di Desa Adat Senaru Kecamatan Bayan Kabupaten Lombok Utara. Subjek dari kegiatan pengabdian masyrakat ini adalah seluruh anak-anak di Desa Adat Senaru yang berusia SD antara 7-12 tahun yang berjumlah 43 anak, Pelaksanaan kegiatan pengabdian ini terbagi dalam tiga tahap sesuai dengan moto Desa Adat Senaru adalah "ontas onang onyak" yang bermakna "ketika ingin melaksanakan sesuatu sebaiknya direncankan atau dirintis/direncanakan dengan baik terlebih dahulu agar dinikmati, dirasakan, digunakan, dan dimanfaatkan hasilnya, yang kemudian perlu mempebaiki dan memeliharanya agar bisa digunakan kembali baik untuk kebutuhan pribadi atau kebutuhan bersama. Dari moto tersebut dibagi menjadi tiga tahap yaitu: (1) tahap perencanaan, (2) tahap pelaksanaan, (3) tahap evaluasi. Tahap perencanaan telah ditetapkan hal-hal sebagai berikut: tempat/lokasi kegiatan dipilih di Desa Adat Senaru Kecamatan Bayan Kabupaten Lombok Utara. Jenis kegiatan berupa pendampingan dalam meningkatkan motivasi belajar anak-anak Desa Adat Senaru.

1. Sosialisasi dan Perijinan

Sosialisasi dan perijinan merupakan tahap awal kegiatan. Kegiatan ini bertujuan untuk menginformasikan kepada warga desa adat senaru mengenai sasaran dan rencana kegiatan pengabdian. Kegiatan ini dilakukan dengan metode diskusi langsung dengan aparat desa adat, orang tua, dan anak-anak Desa Adat Senaru. 


\section{Persiapan Pendampingan}

Persiapan pendampingan yaitu mempersiapkan bahan-bahan materi pembelajaran SD berupa mata pelajaran matematika dan Bahasa Indonesia serta mempelajari kearifan-kearifan lokal yang akan digunakan pada proses pendampingan

3. Pendampingan berbasis kearifan lokal

Pendampingan dilaksanakaan di luar jam sekolah atau ketika waktu bermain anakanak dengan berbasis kearifan lokal. Materi yang disampaikan dalam kegiatan ini mencakup penyampaian materi mengenai materi matematika SD dan Bahasa Indonesia SD. Penyampaian materinya pun dikemas dengan santai dan tidak terlalu formal yaitu diselingi oleh kearifan lokal yang ada bekerjasama dengan warga stempat yang menguasai kearifan lokal tersebut.

4. Evaluasi proses pendampingan berbasis kearifan lokal

Evaluasi yang dilakukan dalam kegiatan ini dilaksankan dengan tidak terlalu formal namun tetap dilaksanakan evaluasi terkait motivasi belajar siswa dengan menggunakan instrument angket sesuai dengan indikator motivasi belajar.

\section{HASIL DAN PEMBAHASAN}

\section{Hasil}

Kegiatan pengabdian masyarakat dilaksanakan di desa adat Senaru Kecamatan Bayan Kabupaten Lombok Utara. Subjek kegiatan pengabdian ini adalah seluruh anakanak usia SD yang berada di desa Adat Senaru Kecamatan Bayan. Berdasarkan hasil kegiatan pengabdian selama seminggu dalam upaya meningkatkan motivasi belajar siswa melalui pendampingan berbasis kearifan lokal diperoleh data melalui lembar angket motivasi belajar siswa yang dibagikan sebelum dan setelah mengikuti pendampingan tersebut adalah sebagai berikut. 


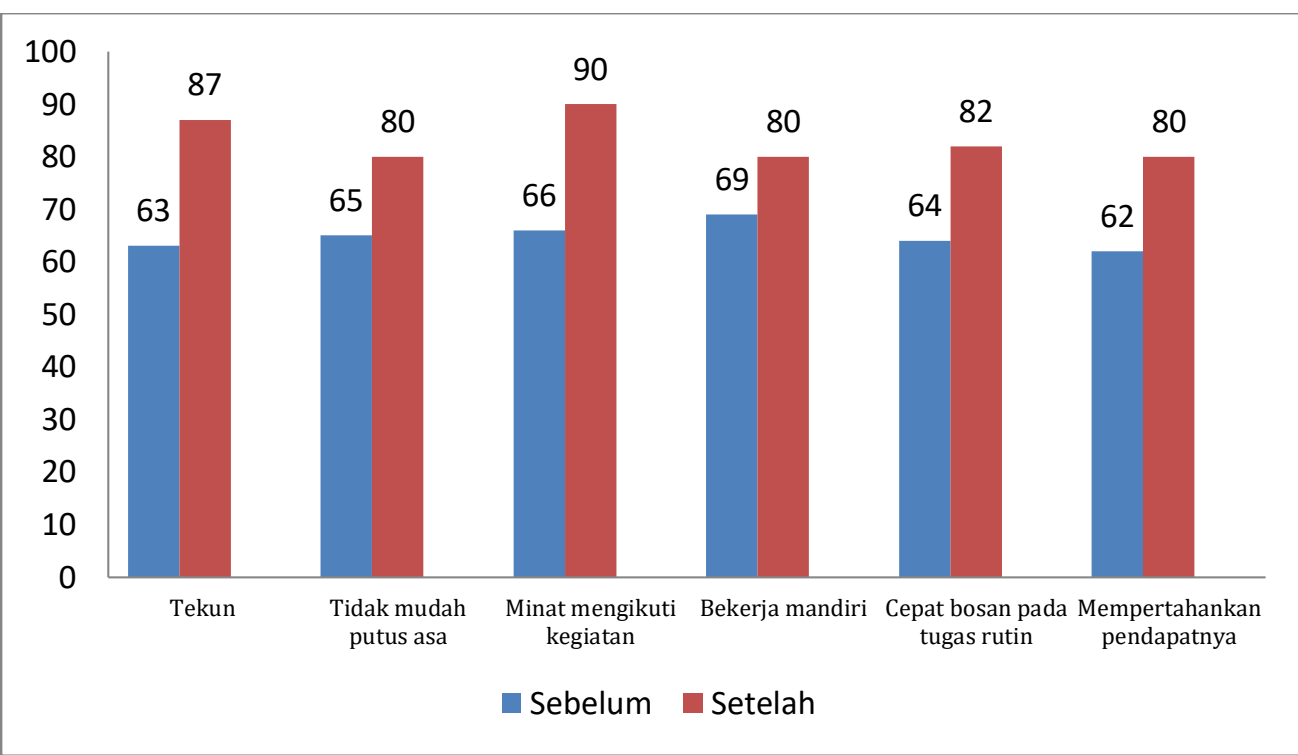

Grafik 1. Hasil angket motivasi belajar siswa sebelum dan setelah melaksanakan pendampingan berbasis kearifan lokal

Dilihat dari grafik di atas, pelaksanaan kegiatan pengabdian kepada masyarakat dalam upaya meningkatkan motivasi belajar siswa memberikan dampak yang positif terlihat dari hasil angket pada grafik 1. sebelum melaksanakan pendampingan nilai rata-rata masing-masing indikator masih cukup rendah namun setelah melaksanakan pendampingan berbasis kearifan lokal terdapat peningkatan pada masing-masing indikator motivasi belajar.

\section{Pembahasan}

Selama proses kegiatan pengabdian kepada masyarakat di Desa Adat Senaru terdapat temuan-temuan menarik. Temuan tersebut antara lain kearfian lokal yang digunakan pada proses pendampingan hanya dikuasai oleh beberapa warga desa adat senaru sehingga perlu waktu untuk mempersiapkan kearfian lokal yang digunakan selama proses pendampingan berlangsung seperti mempelajari kearifan lokal, mengatur waktu warga yang akan mengajari kearfian lokal serta hal-hal lainnya. Selain terbatasnya warga yang menguasai kearfian lokal waktu pelaksanaan pendampingan pun harus di persiapakan dengan matang mengingat subjek pengabdian ini adalah anak-anak usia SD yang masih ingin mempunyai waktu banyak untuk bermain.

Dalam menghadapi temuan-temuan tersebut dibutuhkan solusi yang kreatif sehingga proses pendampingan dapat berlangsung dengan lancar sesuai dengan situasi dan kondisi di lapangan. Dengan komunikasi yang baik dengan warga di desa adat 
senaru temuan-temuan tersebut dapat di atasi dan proses pendampingan dapat berjalan dengan baik sehingga hasil pengabdian berupa kegiatan pendampingan memberikan dampak yang positif terhadap peningkatan motivasi belajar anak. Adapun bebrapa kegiatan pendampingan dapat dilihat pada gambar di bawah ini.
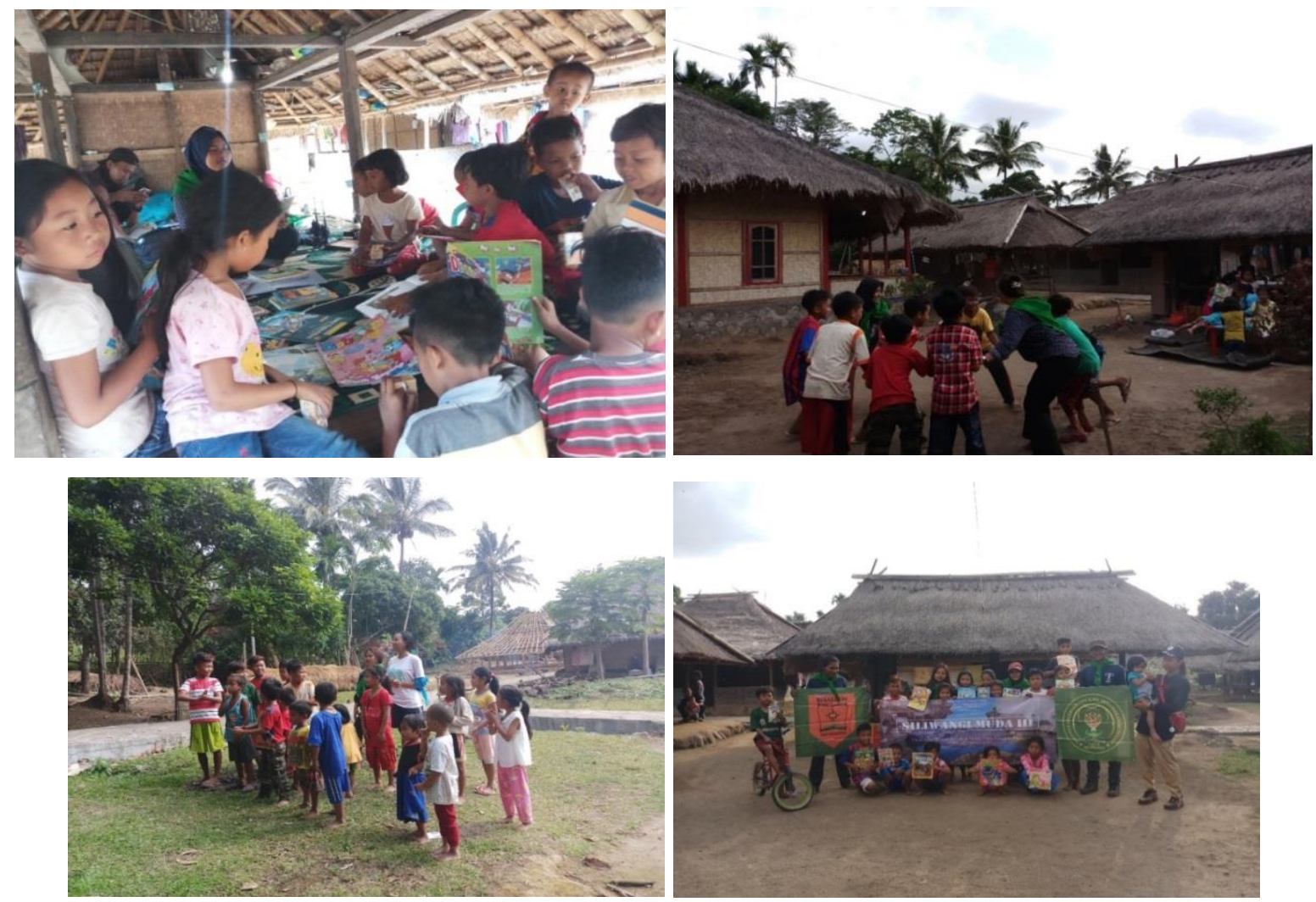

Gambar 1. Kegaiatan Pendampingan Berbasis Kearifan Lokal di Desa Adat Senaru Kecamatan bayan Kabupaten Lombok Utara

\section{E. KESIMPULAN}

Berdasarkan hasil pelaksanaan pengabdian pada masyarakat yang telah dilaksanakan di desa adat Senaru Kecamatan bayan kabupaten Lombok utara, maka dapat disimpulkan hal-hal sebagai berikut:

1. Kegiatan pengabdian pada masyarakat dapat memberikan manfaat langsung kepada anak-anak siswa usia SD dalam meningkatkan motivasi belajar siswa.

2. Kegiatan pengabdian pada masyarakat ini dapat dijadikan sarana berinovasi dalam usaha mengembangkan pembelajaran/pendampingan dalam meningkatkan motivasi belajar siswa.

3. Wahana atau laboratorium bagi para dosen dalam mengimplementasikan teori belajar, kearifan lokal, pengetahuan, dan keterampilan secara nyata, dan bermanfaat bagi masyarakat luas. 


\section{F. DAFTAR PUSTAKA}

Alannasir, W. (2016). Pengaruh penggunaan media animasi dalam pembelajaran IPS terhadap motivasi belajar siswa kelas iv sd negeri mannuruki. Journal of EST, 2 (2), 81- 90.

Anggramayeni, A, dkk. (2018). Efektivitas bahan ajar berbasis kearifan lokal terhadap aktivitas dan hasil belajar peserta didik. Jurnal Bioterdidik, 6 (5), 1-11.

Efendi, A. (2014). Implementasi Kearifan Budaya Lokalpada Masyarakat Adat Kampung Kuta Sebagai Sumber Pembelajaran IPS. Jurnal Sosio Didaktika, 1 (2), 211-218.

Mangewa, M. (2010). Perencanaan pembelajaran. Makassar: Badan Penerbit UNM.

Rahayu, G.D.S dan Firmansyah, D. (2018). Pengembangan pembelajaran inovatif berbasis pendampingan bagi guru sekolah dasar. Jurnal Abdimas Siliwangi, 1 (1), 17-25.

Suprihatin, S. (2015). Upaya guru dalam meningkatkan motivasi belajar siswa. Jurnal Promosi, 3 (1), 73-82.

Widianti, A.K. (2017). Reservasi rumah adat desa sade rembitan Lombok sebagai upaya konservasi. Jurnal Vitruvian, 6 (3), 79-84. 